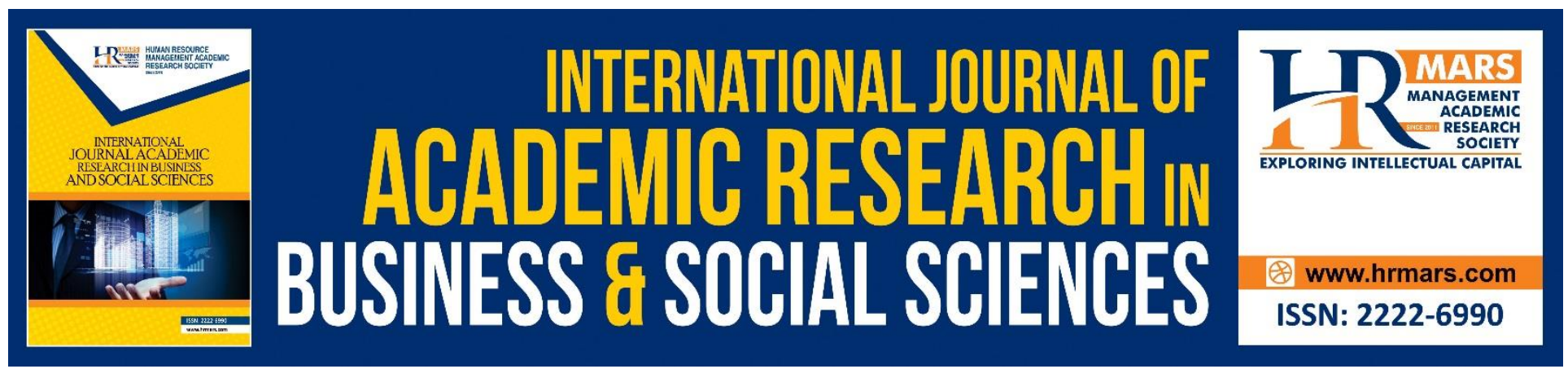

\title{
Comparative Assessment of the Effect of Pre-Knowledge of Reward on the Learning of Male and Female Pupils at the Primary School Level
}

Onolemhemhen P.E, Ebhota E.E.

To Link this Article: http://dx.doi.org/10.6007/IJARBSS/v8-i11/4920

DOI: $10.6007 /$ IJARBSS/v8-i11/4920

Received: 17 Sept 2018, Revised: 29 Oct 2018, Accepted: 16 Nov 2018

Published Online: 28 Nov 2018

In-Text Citation: (Onolemhemhen \& Ebhota, 2018)

To Cite this Article: Onolemhemhen, P., \& Ebhota, E. E. (2018). Comparative Assessment of the Effect of PreKnowledge of Reward on the Learning of Male and Female Pupils at the Primary School Level. International Journal of Academic Research in Business and Social Sciences, 8(11), 452-462.

Copyright: (C) 2018 The Author(s)

Published by Human Resource Management Academic Research Society (www.hrmars.com)

This article is published under the Creative Commons Attribution (CC BY 4.0) license. Anyone may reproduce, distribute, translate and create derivative works of this article (for both commercial and non-commercial purposes), subject to full attribution to the original publication and authors. The full terms of this license may be seen at: http://creativecommons.org/licences/by/4.0/legalcode

Vol. 8, No. 11, 2018, Pg. 452 - 462

Full Terms \& Conditions of access and use can be found at http://hrmars.com/index.php/pages/detail/publication-ethics 


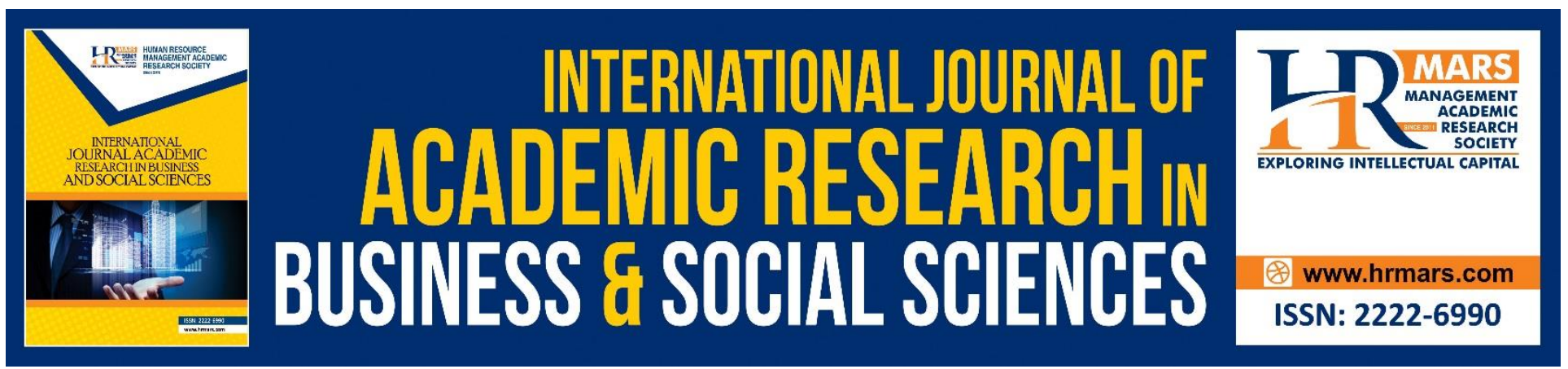

\title{
Comparative Assessment of the Effect of Pre- Knowledge of Reward on the Learning of Male and Female Pupils at the Primary School Level
}

\author{
Onolemhemhen P.E (Phd), Ebhota E.E
}

Department of Guidance and Counselling, Faculty of Education, Ambrose Alli University, Ekpoma

\begin{abstract}
The study is a comparative assessment of the effect of pre-knowledge of reward on the learning of male and female pupils at the primary school level. The Quasi experimental method was employed in the study. Two (2) classes of primary five pupils (120) in number in Uwendova Primary School, Edo State of Nigeria were used as participants. The MacMillan Primary School English course Book five and the National common entrance Examination were used for the pre and post test respectively. ANOVA and Turkey Kramer Multiple comparison statistics were used to assess the result. The finding of the study revealed that female pupils compared to male significantly recorded higher score. It was therefore concluded from the study that reward for learning is more beneficial to female than the male pupils at primary school level. It was therefore recommended that pupils at these primary school level especially females be made aware of the reward accompanying their learning for effective learning to take place.
\end{abstract}

\section{INTRODUCTION}

The convention of the child defines a child as any one below the age of 18 (Nzeako 2011). Children worldwide are bedeviled with a lot of problems. This concern about the situation of children throughout the world culminated in the convention of the rights of child in 1989. The double vulnerability and negative impact felt throughout one's life being a female child led the United Nation International Children and Education Fund UNICEF) To focus more attention on the special needs and constraint on the girl-child as a separated area of concern.

Foremost among the four major objectives is enhancing possible elimination of discrimination against girls in areas of education and training, health and nutrition. Nigeria has evolved series of program to improve girl child education. Among these are Universal Primary Education (UPE), National Mass Literacy Campaign (NMLC) and Universal Basic Education (UBE). Education of the girl-child received further boost when Nigerian Government endorsed the Jomtien Conference of 1990 on Education for all (EFA) by the year 2000 and in 1993, Nigeria re-established the National Primary Education 
INTERNATIONAL JOURNAL OF ACADEMIC RESEARCH IN BUSINESS AND SOCIAL SCIENCES

Vol. 8, No. 11, Nov, 2018, E-ISSN: 2222-6990 @ 2018 HRMARS

Commission (NPEC) which was dissolved in 1991 and given responsibility for pursing EFA for primary level (Ohire-Aniche 1998).

The hindrance of girls education in Nigeria anchor on various factors, Cultural, Societal and Economics (Neako 2011). A case study indicates that both male and female teachers do not give enough opportunity for classroom participation (Ohiri-Aniche1988). Economics factors associated with parental poverty have been associated with impediment to the education of girls (Neako 2011). This study therefore investigated whether learning capability is gender sensitive on a level playing ground.

\section{STATEMENT OF THE PROBLEM}

Primary school is the basis of educational development. The primary school child needs to be encouraged to have personal development and self expression through the school English is used in Nigeria as the medium of instruction from kindergarten to tertiary level of education. There are however a lot of problems or set back in the teaching and learning of the subject many researchers like Osunde and Ogiegbaen (2005), have tried to investigate some of the problems which include lack of infrastructural facilities poor instructional techniques, student apathy towards the subject, few English teachers in schools, lack of instructional materials and the use of pidgin English. These researchers have also recommended different strategies that will enhance the performance of students in English language in Nigeria. Despite the performance of students in English language is still poor as shown in the table below:

Table I: Statistics of entries and results for SSCE, WAEC English Language

\begin{tabular}{|c|c|c|c|c|}
\hline \multirow[t]{2}{*}{ Year } & \multirow[t]{2}{*}{ Number of candidate } & \multicolumn{3}{|c|}{ percentage } \\
\hline & & Grade 1-6 & Grade 7-8 & Grade Fg \\
\hline 2000 & 850,479 & 14.88 & 34.29 & 44.07 \\
\hline 2001 & $1,025,027$ & 26.07 & 30.90 & 43.02 \\
\hline 2002 & 909,888 & 24.57 & 32.81 & 42.61 \\
\hline 2003 & 929,271 & 27.03 & 34.45 & 33.00 \\
\hline
\end{tabular}

Source: Department of Statistics, West Africa Examination Council, Lagos.

Key

Grade 1-3 = Distinction

Grade 4-6 = Credit

Grade $7-8=$ pass

Grade 9 = Fail

From the above table, it could be observed that despite of different techniques and the use of improved instructional materials by the investigators, to improve students' performance in English Language, no appreciable result has been achieved. This study therefore focuses on the use of foreknowledge of reward on students' performance in English Language

An extensive internet and library search also have shown few literatures in Nigeria on the "effect of fore knowledge of reward on students'academic performance" Evidence available in literature based on report on American Journal of Pharmaceutical Education (2006) clearly shows that there is positive link between incentive and students performance. 
INTERNATIONAL JOURNAL OF ACADEMIC RESEARCH IN BUSINESS AND SOCIAL SCIENCES

Vol. 8, No. 11, Nov, 2018, E-ISSN: 2222-6990 @ 2018 HRMARS

This study therefore investigates the effect of pre-knowledge of reward on the learning male and female pupils at the primary school level.

\section{RESEARCH HYPOTHESIS}

There is no significant difference between the performance of male and female pupils who received foreknowledge of reward.

\section{SCOPE OF THE STUDY}

The study covers only English language as a subject because English language is a sore course which must be credited at the primary and secondary school level before any student can gain admission into secondary school or tertiary institutions of learning

\section{REVIEW OF RELATED LITERATURE}

\section{Concept of English Language and types of reward}

The history of English Language in Nigeria is rooted in Nigeria's colonial encounter with Britain in the early $19^{\text {th }}$ century. It was the early European Christian missionaries that propagated the language for their own evangelical purpose. Initially, Nigerians were taught the rudiments of the language to enable them to function as interpreters, Clarks, pastors and catechists. I n Nigeria, the English Language is used as the official and international Language. It is essentially used as a second language sine more than four hundred ethnic groups in the country have their first indigenous language, Quartey, Salawu, Lawal Inyang Adamu and Olatoye (2006)

In an effort to improve students cognitive Affective and Psychomotor domain in English Language has been on since the early 1960s. As early as 1960, attempts were made to address the learning and Instruction of English Language. For example, various commissions and reports such as the Grieve Report (1964) and Banjo Commission (1977) were put in place by the Government to find out ways to improve the teaching of English Language. Banjo (1977) and Wing (1993) spelt out four important for measure proficiency in English Languagae. They include listening, speaking, reading and writing.

This trend of general poor performance in English Language as reported by Osunde and Ogiegbaen (2001) in their study states that the awful poor performance in SSCE English Language has been a source of concern to all stakeholders in Education In Nigeria. He further reported that the World Bank report scored Nigerian graduate low in English language. According to them these graduate exhibit poor abilities in the oral and written expression in English language .... if education is a process of changing the behavior patterns of people, then the behavior pattern of Nigerian students need to be changed right from the primary school level.

Reward is satisfaction of needs for a whole series of responses. In a school system, teachers provide rewards to motivate students to master assigned materials and achieve learning goals, (Eduwen 2003). A reward is something you give to a person or group of persons for diligently doing a piece of work repeatedly, consistently and thoroughly without complaining, with the aim of getting positive result. Reward given to pupils is to make them want to work harder. It can be for coming to school early, cleaning the teachers' seat, blackening the chalkboard, sweeping the school path, returning money or handset found on the ground, taking part in class discussion etc. the type of 
reward given to pupils may be a hand clap, exemption from labour, a ruler, novel, a pencil and an exercise book. The child can also be made a school prefect and they can go on excursion.

There are two types of rewards, intrinsic and extrinsic rewards.

(1) Intrinsic rewards are those things, which the students have haige degree of self control which are an integral part of the learning activity itself, intrinsic rewards are like self imposed motivation that goes deep down in to our personality, it make us happy, it gives satisfaction, it makes us thi we are important and when we feel all this, they provide us stronger support for learning. it also helps us to develop skills and understanding, skills are physical and mental abilities that require a high degree of co-ordination between body and brain.

Physical skills can be seen in athletic events such as running, throwing and jumping while mental skills are needed for proficiency in reading and corruption. The manipulative skills are

found in the technical aspects of arts, craft and writing

(2) Extrinsic rewards are of the learning activity itself and are controlled by someone other than the student. In this case, the teachers arouse the children to work hard, to get good marks, get to the top of the class or obtain a certificate. Other examples could be money, privileges, points, and grades, promotions by teachers or parents' approval or the termination of pain or hunger. If a pupil is intrinsically motivated using extrinsic motivator such as reward it will stimulate the pupils into effective learning (Johnson, 1979) as reported by Eduwen, 2003).

These types of rewards are:

- Verbal rewards

- Symbolic rewards

- Token rewards

- Activity rewards

Berrera (2001) stated that types of reward can be explained thus:

Verbal Rewards: praise is the type of reinforcement most commonly used by teachers. This is a great tool for getting students to answer questions and getting them involved in class discussion. This consists of admiring students for correct responses during class, discussions, for accurate homework, improved test scores, good decision etc. the use of responses like "good job" and great answer will stimulate the students to do better in the classroom. The principles of this theory are often used to promote learning and motivate students

Symbolic Rewards: these rewards include things like gold stars. The purpose of symbolic rewards is to help student work towards a goal. Progress chart serves as a record for good behavior and for everyday tha student behaves favorably they get a sticker on the chart next to name. Choosing a student of the month is also a great symbolic reward. Students are motivated to behave and work harder in order to gain the title of student of the month and get their picture pasted up in the hall

Token Rewards: points or chips may seem like they have no value but to students that are very valuable. When points and chips can be exchanged for things of value students will try to get involved in the learning process and pay attention so that they can gain points or chips Activity Rewards: All children love to play and providing students with extra play time for finishing their work will motivate them. 
Reward is related to motivation which refers to force or push behind peoples' behavior, motivation relates to the force acting on or within an individual to initiate and direct behavior. It is used to understand why people behave the way they do in motivation, this behaviour is directed towards goals. Reward can stimulate appropriate behaviour just like motivation.

\section{DESIGN OF THE STUDY}

The Quasi-experimental method was used for the study. Participants were grouped into $A$ (Experimental group), B (Control group) and C (check list). The effect of the variables, both independent and dependent was assessed. The dependent variables were the performance of the Students in English Language which is a core course for the furtherance of Education in any course of your choice at the University level.

\section{POPULATION OF STUDY}

The population of study consisted of primary 5 pupils in Uwendova Primary School Ekpoma, Edo State Nigeria. Uwendova Primary School has a population of 915 pupils, as shown in the class register (2010). Primary 5 pupils were used as the sample for the study and had a population of 120 pupils.

\section{RESEARCH INSTRUMENT}

The researcher constructed 30 test items adopted from the National Common Entrance Examination questions, this was used as pre-test. Another 30 items for post test was adapted from the National Common Entrance Examinations which consist of the scheme of work drawn from the Macmillan Primary English Course book 5 used for their teaching. The post test was administered after six weeks to get the effect of foreknowledge of reward on the experimental group. Subjects were informed of the different kinds of reward that would accompany their effective learning.

The focus in this study was the use of synonym, tense of the verb, reading comprehension passages, punctuation marks, and words and opposite. Topics were drawn from chapter one to six of the textbook. At each study, pupils were subjected to written exercises. Rating score format was adapted and modified from Iseguan (2000). Study on "effect of guided questions in reading comprehension on performance of learning in children." Adequate precaution was taken in the construction of the instrument to ensure that it stands the test of content validity. In other to achieve this goal, questions were adapted from an existing instrument in Nationwide Common Entrance book. Kuder \& Richardson (1937) method of computing reliability index reported in Onwuegbu \& Okobia, (2000) was used. Spearman-Brown correlation analysis was used for internal constituency of the test and it was adjudged reliable.

\section{ADMINISTRATION OF THE INSTRUMENT}

The three groups - A (Experimental), B (control) and C (check list) were administered the pretest from questions adapted from the National Common Entrance Examinations after which they were all being taught using the prescribed text (MacMillan Primary English Course Book 5). The experimental group was treated by giving the pupils a foreknowledge of the reward accompanying their learning (lunch during break) while the control group was not given such pre-knowledge. 
INTERNATIONAL JOURNAL OF ACADEMIC RESEARCH IN BUSINESS AND SOCIAL SCIENCES Vol. 8, No. 11, Nov, 2018, E-ISSN: 2222-6990 (C) 2018 HRMARS

The post-test was carried and after six weeks of teaching while questions were again adapted from the National Common Entrance Examinations for the post - test.

\section{METHOD OF DATA ANALYSIS}

One-way analysis of variance (ANOVA) was used to mashal out any intervening variable. Post test analysis used was Turkey Kramer test. (SAS Institute, 2001)

\section{RESULTS}

The results presented in Table 1 below contain the number of pupils Male (M) and Female (F) that score in the respective score grades.

Table 1: Number of male (M) and Number of Female (F) that had score in respective score grade.

Result Table 1

\begin{tabular}{|l|l|l|l|l|l|l|}
\hline \multirow{2}{*}{$\begin{array}{l}\text { Score } \\
\text { group }\end{array}$} & A & & B & & C & \\
\cline { 2 - 7 } & M & F & M & F & M & F \\
\hline $30-28$ & 5 & 6 & 3 & 4 & 3 & 4 \\
\hline $27-25$ & 5 & 5 & 3 & 4 & 2 & 3 \\
\hline $24-22$ & 3 & 4 & 4 & 4 & 2 & 3 \\
\hline $21-19$ & 1 & 0 & 2 & 1 & 4 & 5 \\
\hline $18-16$ & 1 & 1 & 2 & 2 & 3 & 2 \\
\hline $15-13$ & 1 & 0 & 1 & 1 & 2 & 2 \\
\hline $12-10$ & 2 & 1 & 1 & 2 & 2 & 1 \\
\hline $9-7$ & 1 & 1 & 2 & 2 & 1 & 1 \\
\hline $6-4$ & 1 & 2 & 2 & 0 & 1 & 1 \\
\hline
\end{tabular}

KEY:

$\mathrm{AM}=$ Experimental male

$\mathrm{AF}=$ Experimental female

$\mathrm{BM}=$ Control male

$\mathrm{BF}=$ Control female

$\mathrm{CM}=$ Checklist male

$\mathrm{CF}=$ Checklist female

In Table 2 below, the mean statistical comparison of experimental, control and checklist for male and female pupils for those that scored grade 30-28 is presented.

\begin{tabular}{|l|l|l|l|l|}
\hline Source of variation & DF & SS & MS & Fcal \\
\hline Between group & 5 & 24.944 & 4.989 & \\
\hline Within group & 12 & 4.667 & 0.3889 & 12.829 \\
\hline
\end{tabular}


INTERNATIONAL JOURNAL OF ACADEMIC RESEARCH IN BUSINESS AND SOCIAL SCIENCES Vol. 8, No. 11, Nov, 2018, E-ISSN: 2222-6990 @ 2018 HRMARS

This showed significant difference $(\mathrm{PL}<0.05)$ in the scores for male compared to the scores for female. Evidence in Table 1 revealed that more female had this grade than male.

Table 2 One-way analysis of variance on the performance of male and female pupils (30-28)

\begin{tabular}{|l|l|l|l|l|}
\hline Source of variation & DF & SS & MS & Fcal \\
\hline Between group & 5 & 24.944 & 4.989 & \\
\hline Within group & 12 & 4.667 & 0.3889 & 12.829 \\
\hline
\end{tabular}

Table 2: One-way analysis of variance on the performance of male and female pupils (27-25)

\begin{tabular}{|l|l|l|l|l|}
\hline Source of variation & DF & SS & MS & Fcal \\
\hline Between group & 5 & 23.111 & 4.622 & \\
\hline Within group & 12 & 5.333 & 0.4444 & 10.400 \\
\hline
\end{tabular}

$P$ value $=0.0005$

Considering the result for those that scored 27-25 as presented in table 2,

Significant $(P<0.05)$ difference can also be observed. More female than male scored this value.

In table 3 below statistical comparison data for male and female score grade 24-22 is presented

Table3

\begin{tabular}{|l|l|l|l|l|}
\hline Source of variation & DF & SS & MS & Fcal \\
\hline Between group & 5 & 14.278 & 2.856 & \\
\hline Within group & 12 & 11.333 & 0.9444 & 3.024 \\
\hline
\end{tabular}

P value $=0.0540$

This further confirm significant $(P<0.05)$ difference with more female in the experimental group scoring this value compared to those of male pupils.

Statistical consideration of lower grade score for instance of 21-19 as shown in Table 4 below revealed significant $(P<0.05)$ difference with less number of female scoring this value compared to number of male. Table 4: One-way analysis of variance on the performance of male and female pupils (21-19)

Table 4

\begin{tabular}{|l|l|l|l|l|}
\hline Source of variation & DF & SS & MS & Fcal \\
\hline Between group & 5 & 51.111 & 10.222 & \\
\hline Within group & 12 & 8.000 & 0.667 & 15.333 \\
\hline
\end{tabular}

$P$ value $<0.0001$

One-way analysis of variance on the performance of male and female pupils for score grade 18-16 is presented in Table 5 below. This also revealed significant difference with less female compared to the score of male pupil's. 
INTERNATIONAL JOURNAL OF ACADEMIC RESEARCH IN BUSINESS AND SOCIAL SCIENCES

Vol. 8, No. 11, Nov, 2018, E-ISSN: 2222-6990 @ 2018 HRMARS

Table 5

\begin{tabular}{|l|l|l|l|l|}
\hline Source of variation & DF & SS & MS & Facl \\
\hline Between group & 5 & 9.111 & 1.822 & \\
\hline Within group & 12 & 4.000 & 0.3333 & 5.467 \\
\hline
\end{tabular}

$P$ value $=0.0075$

The one-way analysis of variance on the performance of male and female pupils in score grade 15-13 is presented in Table 6 below.

Table 6

\begin{tabular}{|l|l|l|l|l|}
\hline Source of variation & DF & SS & MS & Facl \\
\hline Between group & 5 & 4.944 & 0.9889 & \\
\hline Within group & 12 & 6.000 & 0.5000 & 1.978 \\
\hline
\end{tabular}

$P$ value $=0.1546$

Data for comparison for score grade 15-13 is presented in Table 7; score grade 9-8 is presented in Table 8 and that of score grade 9-7 in Table 9

Table 7 one way analysis of variance on the performance of male and female pupils (15-13)

Table 7

\begin{tabular}{|l|l|l|l|l|}
\hline Source of variation & DF & SS & MS & Facl \\
\hline Between group & 5 & 3.11 & 0.622 & \\
\hline Within group & 12 & 3.333 & 0.2778 & 2.240 \\
\hline
\end{tabular}

$P$ value $=0.1172$

Table 8: one-way analysis of variance on the performance of male and female pupils (9-7)

Table 8

\begin{tabular}{|l|l|l|l|l|}
\hline Source of variation & DF & SS & MS & Facl \\
\hline Between group & 5 & 6.278 & 1.256 & \\
\hline Within group & 12 & 4.000 & 0.3333 & 3.767 \\
\hline
\end{tabular}

$P$ value $=0.0278$

Data is significant.

Table 9: one-way analysis of variance on the performance of male and female pupils (6-4)

Table 9

\begin{tabular}{|l|l|l|l|l|}
\hline Source of variation & DF & SS & MS & Facl \\
\hline Between group & 5 & 5.111 & 1.022 & \\
\hline Within group & 12 & 2.667 & 0.2222 & 4.600 \\
\hline
\end{tabular}

$P$ value $=0.0142$ 
INTERNATIONAL JOURNAL OF ACADEMIC RESEARCH IN BUSINESS AND SOCIAL SCIENCES

Vol. 8, No. 11, Nov, 2018, E-ISSN: 2222-6990 (C) 2018 HRMARS

Data is significant. There is significant difference between the performance of male and female students who received foreknowledge of reward (18-16)

\section{DISCUSSION}

It can be observed that significant $(P<0.05)$ difference was recorded in all comparison(s) for number of female/male with higher score with more females scoring higher than number of male pupils. The very lower score grade seem to reflect the innate interest of the studied subjects. Statistics for 15-13 showed less female scoring lower grade compared to their male counterpart. All the evidences seem to establish that foreknowledge of reward is more beneficial to female or promotes learning more in females than male pupils.

This means that learning by female is more encouraging with reward compared with similarly induced male pupils. This suggestion is supported in this study by the number of females that scored 30-28, scored 27-25 and by those that scored 24-22. In the entire score group, more female than male pupils were found to have scored these marks. This high performance of female subjects has been considered to be of "conditioned reinforcement" or token reinforcement learning type (Husle et al 1975). The positive effect of this type of learning has been reported by many scholars (Staat et al 1964, O'Leary and Drabman 1971, Azvin 1968). Significance to this study is the adducible evidence that more reward accrues from female motivation compared to motivation of male subjects under same settings generally, the study has buttressed the need for foreknowledge of reward in learning.

\section{CONCLUSION}

The use of foreknowledge of reward facilitates student's performance in English language it can therefore be applied in schools in the study of English Language to bring about positive changes in students' performance

It can be deduced from the study that foreknowledge of reward enhances the academic performance of female students than the male students. It is therefore recommended for the teaching of Primary School pupils especially the female pupils.

\section{REFERENCES}

Banjo, A. (1997) "The Goals of Language education in Nigeria" Bamgbose, (ed) Language education in Nigeria (I) 16

Barrera, C. (2006): Social and cultural foundations of American education: what are reward systems and do they work? Retrieved on $5^{\text {th }}$ June 2009 from http//en.wikibooks.org/wiki/

Eduwen, F.O. (2003): Elements of human learning. Benin City: Ogunlere Publishers 6: 78-84

Iseguan, A. (2009): Study on the effect of guided questions in reading comprehension on performance of learning disabled children: Unpublished Ph.D Dissertation. Ambrose Alli University, Ekpoma.

O'Leary, K.D. and Drabment, R. (1971) Token reinforcement programs in the classroom. A review. Psychol. Bull. 75, 379-398

Osunde, A.U. and Ogiegbaen, S.E. (2005) An assessment of factors associated with student's poor performance in Senior School Certificate English Language in Nigeria; Language in India Vol. 5 http;://www.languageinindia.com/april2005englishnigeira1.html. 
Quartey, S.M., Salami, A., Lawal, M.B., Inyang, M., Adamu, S. and Olatoye, T.O. (2006): Lantern Comprehensive Social Studies for Primary /schools; Lantern Books; Literamed Publication Nigeria Limited Printing Press Division, Ikeja Lagos. 2: 4-6

SAS Institute (2001) SAS/STAT User's Guide version and Ed SAS inst. Inc. Cary N.C. USA.

Staats, A., Finley, J., Minse, K.A., Wolf, M. (1964) Reinforcer System and experimental procedure for the laboratory study of reading acquisition Child development 35, 209-231. 